\title{
Modulus of Elasticity and Poisson's Ratio for Types 17-4 PH and 410 Stainless Steels in Compression
}

\section{T. Robert Shlves Richard J. Flelds}

U.S. DEPATTMENT OF COMMERCE Netionsl institute of Standards and Technoloty Manufacturing Endineering Laboratory enthorbur, MD 20899

\section{Propared for Lborty Technolodes Lo Park 588 North Lane}

Conshohocken, PA 19428-2208
U.S. DEPARTMENT OF COMMERTE Robert A. Mochacher, Secretary MATONAL MSTIUUTE OF STANDARDS NDT TEHNOLOOY Joh W. Lyons, Director 



\section{Modulus of Elasticity and Poisson's Ratio for Types 17-4 PH and 410 Stainless Steels in Compression}

\section{T. Robert Shives Richard J. Fields}

U.S. DEPARTMENT OF COMMERCE National Institute of Standards and Tochnotogy Manufacturing Englneering Laboratory Calthorsburg, MD 20899

Prepared for

Uberty Technologies

Loo Park

555 North Lane

Conshohocken, PA $19428-2208$

August 1991

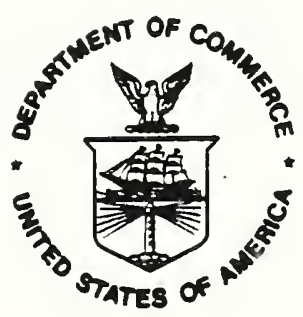

U.S. DEPARTMENT OF COMMERCE Robert A. Mosbacher, Secretary NATIONAL INSTITUTE OF STANDARDS AND TECHNOLOGY John W. Lyons, Director 



\section{Abstract}

Values of the modulus of elasticity and Poisson's ratio in compression were determined for three samples of type 17-4 PH stainless steel and for one sample of type 410 stainless steel. The three samples of the 17-4 $\mathrm{PH}$ were from different locations of one bar of material. The results obtained agree well with values reported in the literature.

\section{Introduction}

As requested by Liberty Technologies, the NIST Mechanical Properties and Performance Group determined the modulus of elasticity (E) and Poisson's ratio ( $v)$, both in compression, for samples of types 17-4 $\mathrm{PH}$ and 410 stainless steels that were supplied by the company.

\section{Specimen preparation}

The 17-4 PH stainless steel was supplied in the form of a cylindrical bar $4.13 \mathrm{~cm}$ (1 $5 / 8$ inches) in diameter and $114.3 \mathrm{~cm}(45$ inches) long. Three cylindrical specimens, nominally $3.81 \mathrm{~cm}(1.5$ inches) long and $1.27 \mathrm{~cm}(0.5 \mathrm{inch})$ in diameter, were machined by the NIST Fabrication Technology Division from this bar. One specimen was taken from each end of the bar and one was taken from the center (measured lengthwise) as shown in figure 1. The longitudinal axes of all three specimens were coincident with the longitudinal axis of the bar. The specimens were designated A, B$C$, and $D$, as shown in figure 1. The two bar lengths between the specimens were designated $A-B$ and $C-D$. These designations were given to the component ends as shown in the figure so that the component position and orientation within the bar could be maintained.

These specimens were prepared by first removing slightly oversize cylinders from the bar by electrical discharge machining (EDM). Machining of the cylinder surface was completed by centerless grinding to an 8 to 16 microinch finish. The ends of each specimen were ground flat and parallel to within $0.00025 \mathrm{~cm}(0.0001$ inch).

Two machined specimens each of 410 and 416 stainless steel were also received from Liberty Technologies. These specimens were nominally $3.81 \mathrm{~cm}$ ( 1.5 inches) long and $1.27 \mathrm{~cm}(0.5$ inch) in diameter when received. The ends were machined flat and parallel to within $0.00025 \mathrm{~cm}(0.0001$ inch) at NIST in the same manner as the specimens of 17-4 $\mathrm{PH}$.

\section{Test Procedure}

The three 17-4 PH specimens and one of the 410 specimens were tested. The second 410 specimen and neither of the 416 specimens were tested in accordance with instructions from Liberty Technologies. Both $\mathrm{E}$ and $v$ were determined by testing the specimens in compression using an Instron universal testing machine, model 
no. TTCML, serial no. 1598. The load applied to the specimen during testing was measured with a load cell. The load cell was calibrated against a $4535.9 \mathrm{~kg}(10,000 \mathrm{lb})$ capacity Morehouse proving ring, number 80 , that itself had been calibrated and certified by the NIST Force Measurements Group. A copy of the Report of Force Calibration for the proving ring is attached as Appendix A.

The initial length and diameter of specimens tested were determined to the nearest $0.00025 \mathrm{~cm}(0.0001$ inch). Axial and diametral displacements of the specimens during load application were measured with extensometers. The axial extensometer was MTS model no. 632.11B-20, serial no. 925. The diametral extensometer was MTS model 632.19B-20, serial no. 238. Both extensometers were calibrated with a micrometer head which could be read to the nearest $0.000025 \mathrm{~cm}(0.00001$ inch). This m vrometer head was calibrated by the NIST Calibration Services Grou. The certificate of test is given in Appendix B.

Both the modulus of elasticity and Poisson's ratio must be determined from elastic changes in the dimensions of the specimen when it is under load. In order to make several tests or runs on any given specimen, it was important not to stress the specimen to the point of yield. Because of the general relationship between hardness and strength, Rockwell C hardness measurements were made on two of the 17-4 PH specimens and Rockwell 30T measurements were made on the 410 specimen to determine the approximate strengths of the materials. The results of these measurements are given in Table 1. The hardness of the 17-4 PH stainless steel suggests that this material is in either the annealed condition or has been given a H1150 temper ${ }^{1,2}$ and would be expected to have a tensile strength of approximately 793 to $1034 \mathrm{MPa}$ (115 to $150 \mathrm{ksi}$ ) and a yield strength of about 517 to $758 \mathrm{MPa}$ (75 to $110 \mathrm{ksi}$ ). The maximum loads applied to the 17-4 PH specimens and the 410 specimens were nominally $4545 \mathrm{kgf}(10,000 \mathrm{lbf})$ and $2727 \mathrm{kgf}$ (6000 lbf), respectively. These loads were well below the estimated yield strengths of the materials. All tests were run at a crosshead speed of $0.5 \mathrm{~mm}$ (0.02 in) per minute. A data acquisition system recorded outputs from the load cell and the extensometers at a rate of 5 times per second.

\section{Test Results}

The values for the modulus of elasticity, Poisson's ratio, and E/v for three specimens from the bar of 17-4 PH stainless steel and for one of the 410 stainless steel specimens are presented in Table 2. The values given in the table are averages based on the results of a number of runs for each specimn. A representative $p$ ot of axial and diametra displacement vers : load for 17-4 PH secimen $A$ is shown in figure 2. Similarly, a cepresentative plot of axial and diametral displacement versus liad for the 410 stainless steel specimen is shown in figure 3 .

Values for the modulus of elasticity reported in the literature ${ }^{3}$ 
are $193 \mathrm{GPa}\left(28 \times 10^{6} \mathrm{psi}\right)$ for $17-4 \mathrm{PH}$ stainless steel and $221 \mathrm{GPa}$ $\left(32 \times 10^{6}\right)$ for 410 stainless steel. Values reported for Poisson's ratio are .291 for the 17-4 PH stainless and .27-.29 for the 410 material. The experimental values reported here compare well with the literature values.

\section{References}

1. Structural Alloys Handbook, Volume 2, Battelle Columbus Division, 1987, Wrought Stainless steel selector Chart, pp. $4-7 ; 410$ stainless steel, pp. 2, 12; 17-4 $\mathrm{PH}$ and 15-5 $\mathrm{PH}$ Stainless steel, pp. 16-17.

2. Metals Handbook, 9th edition, Volume 3, American Society for Metals, 1980, pp 26, 29.

3. Handbook of stainless steels, Peckner, Donald, and Bernstein, I.M., McGraw-Hill, 1977, pp. 19-2, 19-3. 


\section{Table 1. Results of Hardness Measurements}

\section{Rockwell C Scale Measurements}
17-4 $\mathrm{PH}$ Specimen A 17-4 PH Specimen B-C

\begin{tabular}{ccc}
29.3 & 29.9 \\
& 30.1 & 30.0 \\
29.8 & 30.3 \\
29.4 & 29.8 \\
Average & 28.5 & 29.7 \\
\hline & $\overline{29.4}$ & $\overline{29.9}$
\end{tabular}

Rockwell 30T Scale Measurements

410 Specimen

76.8

77.8

75.8

Average

$\overline{76.8}$ 
Table 2. Results of Modulus of Elasticity and Poisson's Ratio Measurements

17-4 $\mathrm{PH}$ stainless steel specimen $\mathrm{A}$

Modulus of elasticity (E): $194 \pm 0.48 \mathrm{GPa}\left(28.10 \pm 0.07 \times 10^{6} \mathrm{psi}\right)[ \pm 0.2 \%]$
$643 \pm 6.89 \mathrm{GPa}$
E/v: Poisson's ratio $(v): \quad 0.30 \overline{1} 4 \pm 0.0025[ \pm 0.8 \%]$

17-4 PH stainless steel specimen B-C

Modulus of elasticity (E): $192 \pm 0.21 \mathrm{GPa}\left(27.80 \pm 0.03 \times 10^{6} \mathrm{psi}\right)[ \pm 0.1 \%]$
$637 \pm 0.34 \mathrm{GPa}$
E/v: Poisson's ratio $(v)$ :

$0.30 \overline{1} 1 \pm 0.0001[ \pm 0.0 \%]$

17-4 PH stainless steel specimen $D$

Modulus of elasticity (E): $192 \pm 0.21 \mathrm{GPa}\left(27.88 \pm 0.03 \times 10^{6} \mathrm{psi}\right)[ \pm 0.1 \%]$
$633 \pm 3.65 \mathrm{GPa}\left(91.74 \pm 0.53 \times 10^{6} \mathrm{psi}\right)[ \pm 0.6 \%]$ Poisson's ratio $(v)$ : $0.30 \overline{3} 7 \pm 0.0012[ \pm 0.4 \%]$

Average values for the 17-4 $\mathrm{PH}$ stainless steel rod

Modulus of elasticity (E): $193 \pm 1.10 \mathrm{GPa}\left(27.92 \pm 0.16 \times 10^{6} \mathrm{psi}\right)[ \pm 0.6 \%]$
$637 \pm 5.17 \mathrm{GPa}\left(92.43 \pm 0.75 \times 10^{6} \mathrm{psi}\right)[ \pm 0.8 \%]$
E/v: Poisson's ratio $(v)$ : $0.30 \overline{2} 1 \pm 0.0014[ \pm 0.5 \%]$

410 stainless steel

Modulus of elasticity (E): $220 \pm 1.45 \mathrm{GPa}\left(31.98 \pm 0.21 \times 10^{6} \mathrm{psi}\right)[ \pm 0.7 \%]$
$774 \pm 17.0 \mathrm{GPa}\left(112.30 \pm 2.46 \times 10^{6} \mathrm{psi}\right)[ \pm 2.1 \%]$
E/v: Poisson's ratio $(v)$ $0.28 \overline{5} 6 \pm 0.0072[ \pm 2.5 \%]$ 


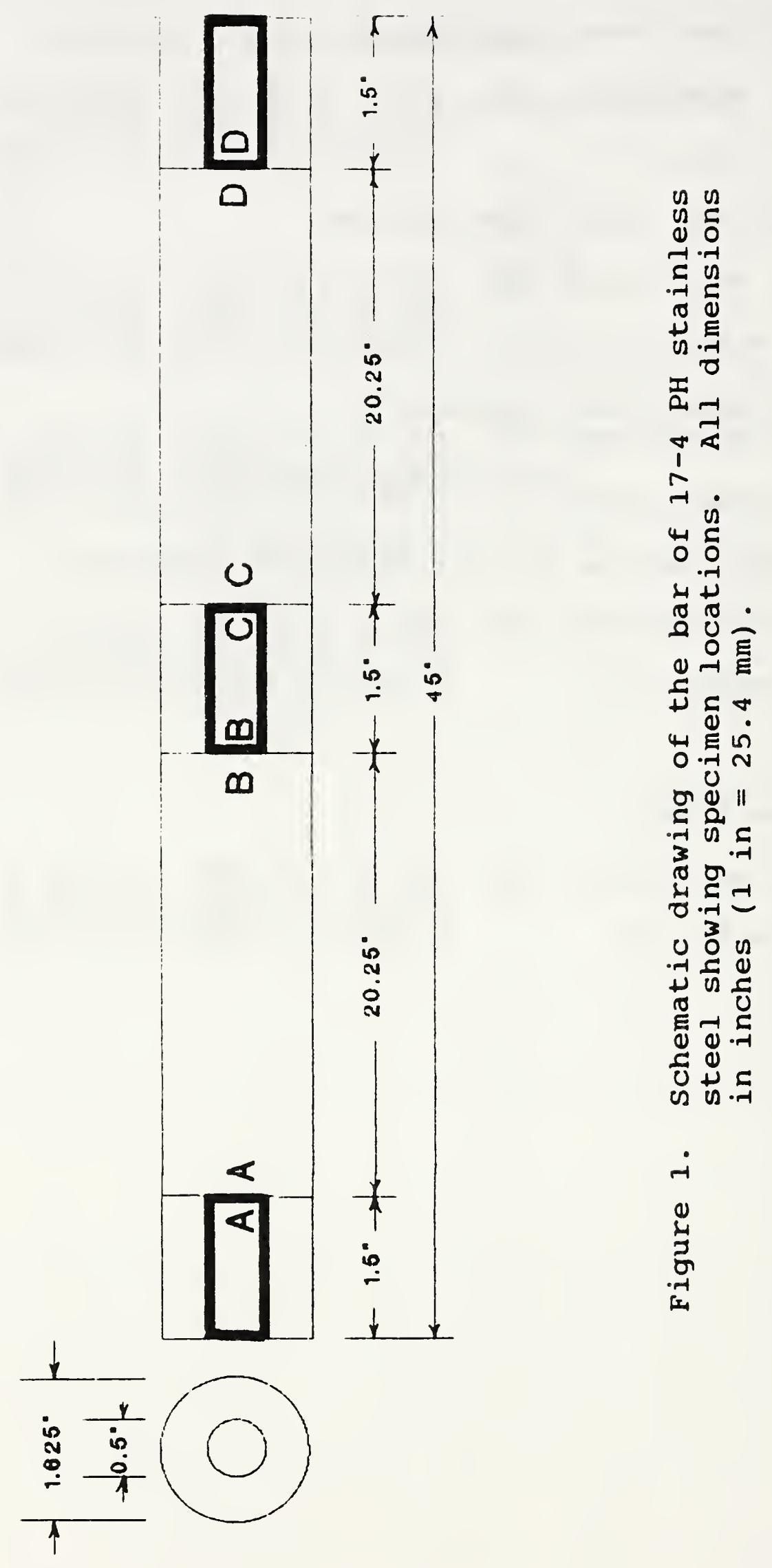




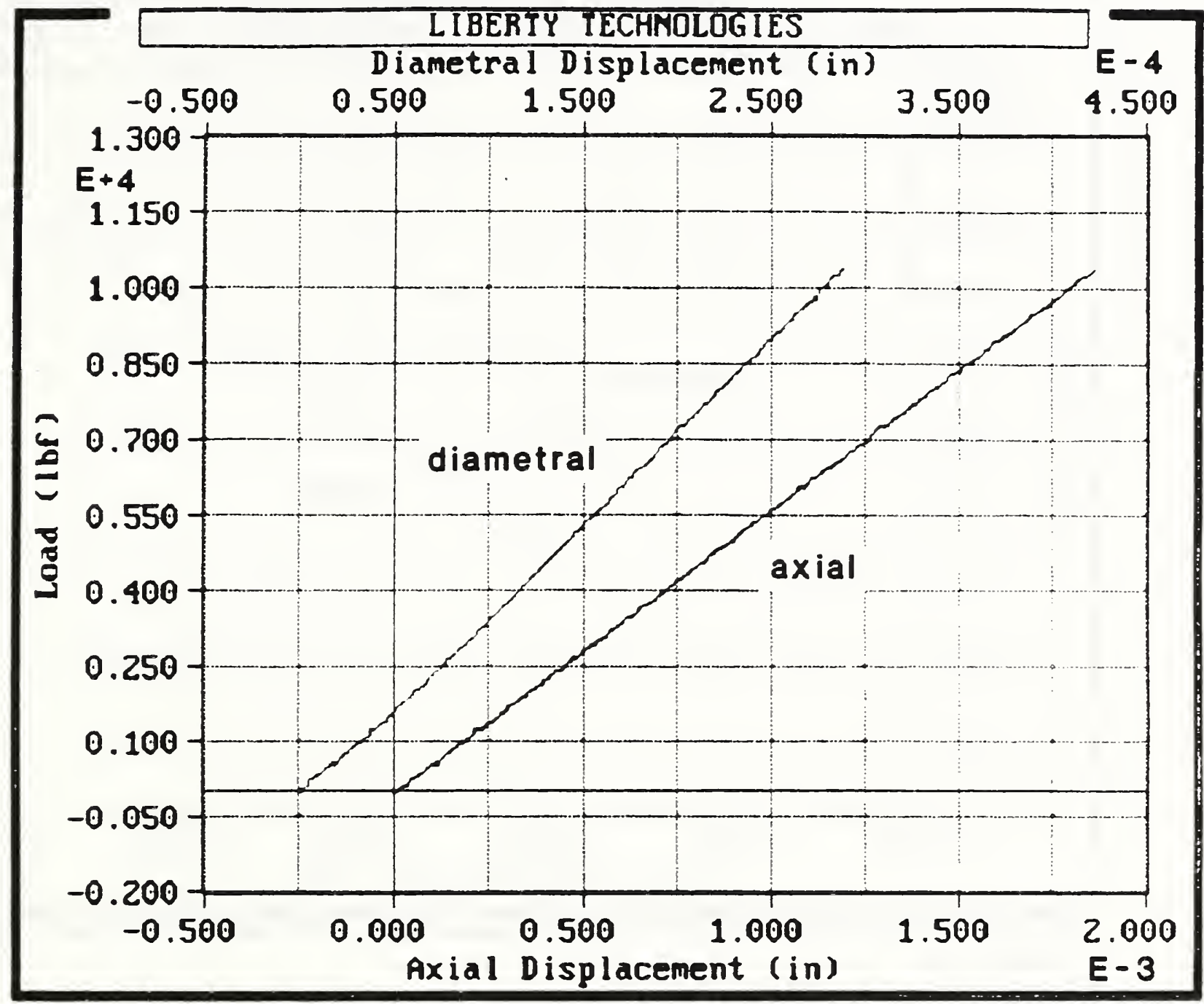

17-4 PH A $\$ 32$

$24.0^{\circ} \mathrm{C} \quad 75.2^{\circ} \mathrm{F}$

Figure 2. Representative plot of axial and diametral displacement versus load for specimen A from the bar of 17-4 PH stainless steel. Length dimensions are in inches ( 1 in $=25.4 \mathrm{~mm}$ ). Load is in pounds force ( 1 lbf $=0.45359 \mathrm{kgf}$ ). 


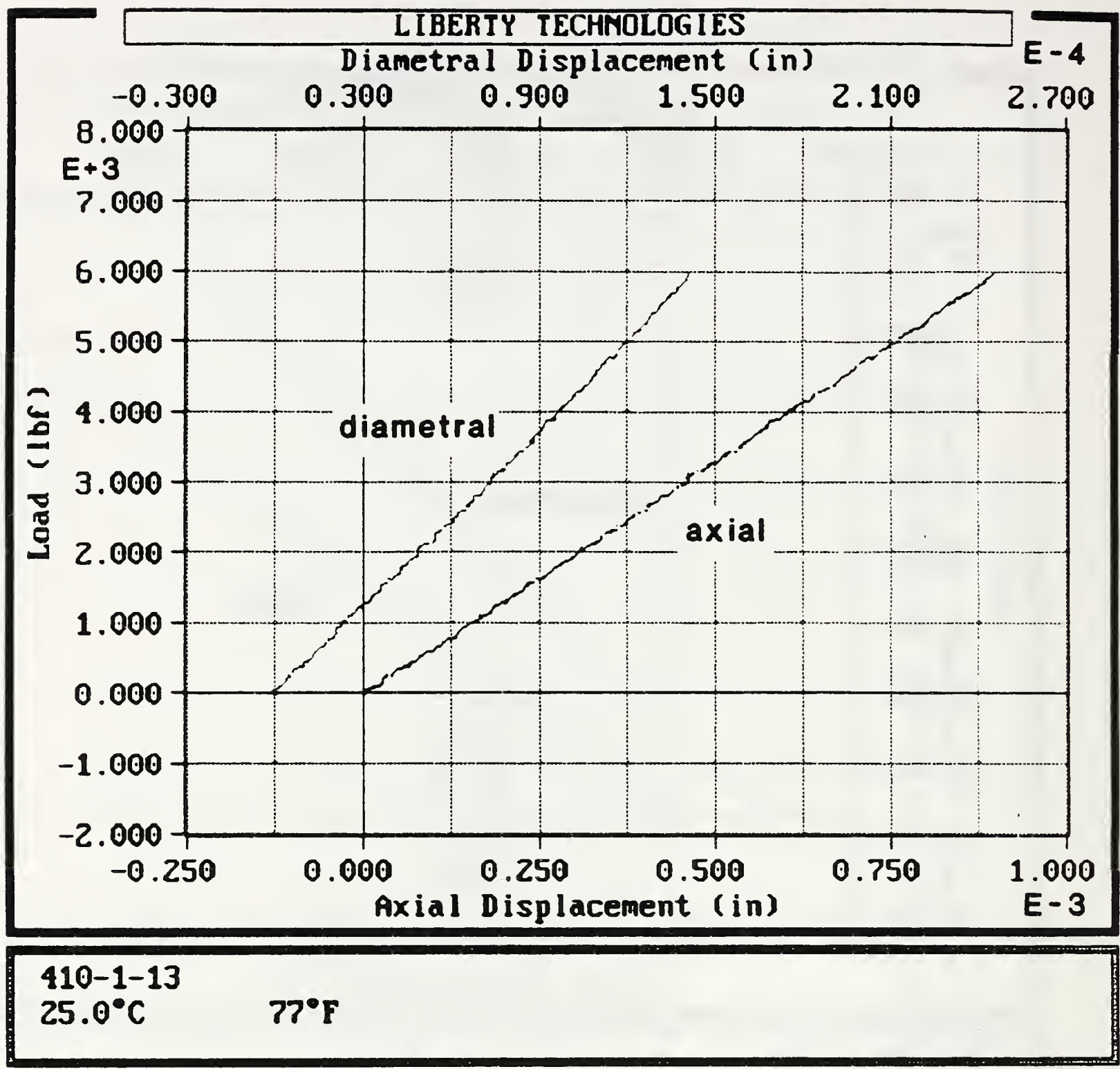

Figure 3. Representative plot of axial and diametral displacement versus load for the 410 stainless steel specimen. Length dimensions are in inches $(1$ in $=25.4 \mathrm{~mm})$. Load is in pounds force ( $1 \mathrm{lbf}=0.45359 \mathrm{kgf}$ ). 
Appendix A

Proving Ring No. 80 Calibration 
NATIONAL INSTITUTE OF STANDARDS AND TECHNOLOGY

(formerIY NATIONAL BUREAU OF STANDARDS)

REPORT OF FORCE CALIBRATION

Test No. $822.07 / 910701$

Calibration Date: July 1, 1991

Morehouse Proving Ring No. 80

Capacity 10000 lbf Compression

National Institute of Standards and Technology

Gaithersburg, Maryland

Purchase Order: $855-4643$

Dated: May 28, 1991

The above force measuring device was calibrated in accordance with ASTM E74-83, "Standard Practices of Calibration of Force Measuring Instruments for Verifying the Load Indication of Testing Machines". The attached calibration data applies only when this device is used in a manner consistent with those procedures.

Calibration loads were applied by dead weights. Errors in the applied loads due to uncertainties in the adjustment of the weights and variations in air density did not exceed 0.002 percent.

The calibration data for a temperature of 23 degrees celsius with analysis are enclosed.

Note: This is a report of a force calibration. To use this device for measuring mass, the effects of local gravity and air buoyancy must be taken into account.

For the Director,

National Institute of Standards and Technology

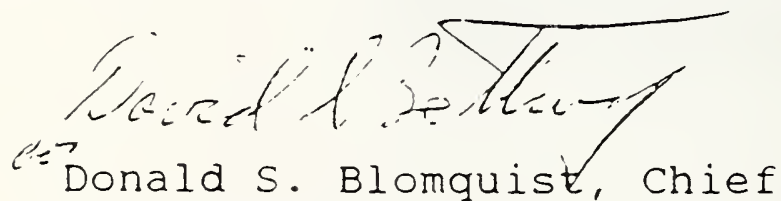

Automated Production Technology Division

Manufacturing Engineering Laboratory

Enclosures 
Calibration Date: July 1, 1991

Morehouse Proving Ring No. 80

Capacity 10000 lbf Compression

Compression Data for 23 Degrees Celsius

$\begin{array}{ccrrr}\begin{array}{c}\text { Applied } \\ \text { Load } \\ \text { Ibf) }\end{array} & \begin{array}{c}\text { Response } \\ \text { Run 1 }\end{array} & \begin{array}{c}\text { Response } \\ \text { Run 2 }\end{array} & \begin{array}{r}\text { Predicted } \\ \text { Response }\end{array} & \begin{array}{c}\text { Change from } \\ \text { Previous } \\ \text { Calibration }\end{array} \\ 700 & 56.58 & 56.75 & 56.70 & 0.01 \\ 1100 & 89.05 & 89.15 & 89.12 & -0.01 \\ 1900 & 154.20 & 154.25 & 154.13 & -0.04 \\ 2300 & 186.70 & 186.80 & 186.72 & -0.06 \\ 3100 & 252.00 & 252.10 & 252.07 & -0.09 \\ 3900 & 317.65 & 317.70 & 317.65 & -0.10 \\ 4700 & 383.35 & 383.45 & 383.46 & -0.12 \\ 5500 & 449.35 & 449.50 & 449.49 & -0.12 \\ 6000 & 490.90 & 490.85 & 490.87 & -0.12 \\ 6500 & 532.42 & 532.27 & 532.35 & -0.12 \\ 7000 & 574.05 & 573.75 & 573.91 & -0.11 \\ 8000 & 657.20 & 657.25 & 657.29 & -0.10 \\ 8500 & 699.30 & 699.20 & 699.12 & -0.08 \\ 9000 & 741.15 & 741.13 & 741.04 & -0.07 \\ 10000 & 825.00 & 825.05 & 825.13 & -0.03\end{array}$

The coefficients of the following equation were fitted to the calib:ation data using the method of least squares. Units for response and load are the same as shown in the above table.

$$
\begin{array}{ll}
\text { Response }= & A+B(\text { load })+C(\text { load })^{2}, \\
\text { where } & A=9.74419 E-02 \\
& B=8.07347 E-02 \\
& B=1.76863 E-07
\end{array}
$$

The following values, as defined in ASTM E74-83, were determined from the calibration data:

$\begin{array}{rlrl}\text { Uncertainty } & =2.8 \text { lbf } \\ \text { Class A Loading Range } & = & 1107 \text { to } & 10000 \text { lbf } \\ \text { Class AA Loading Range } & =\quad 5536 \text { to } & 10000 \text { lbf }\end{array}$



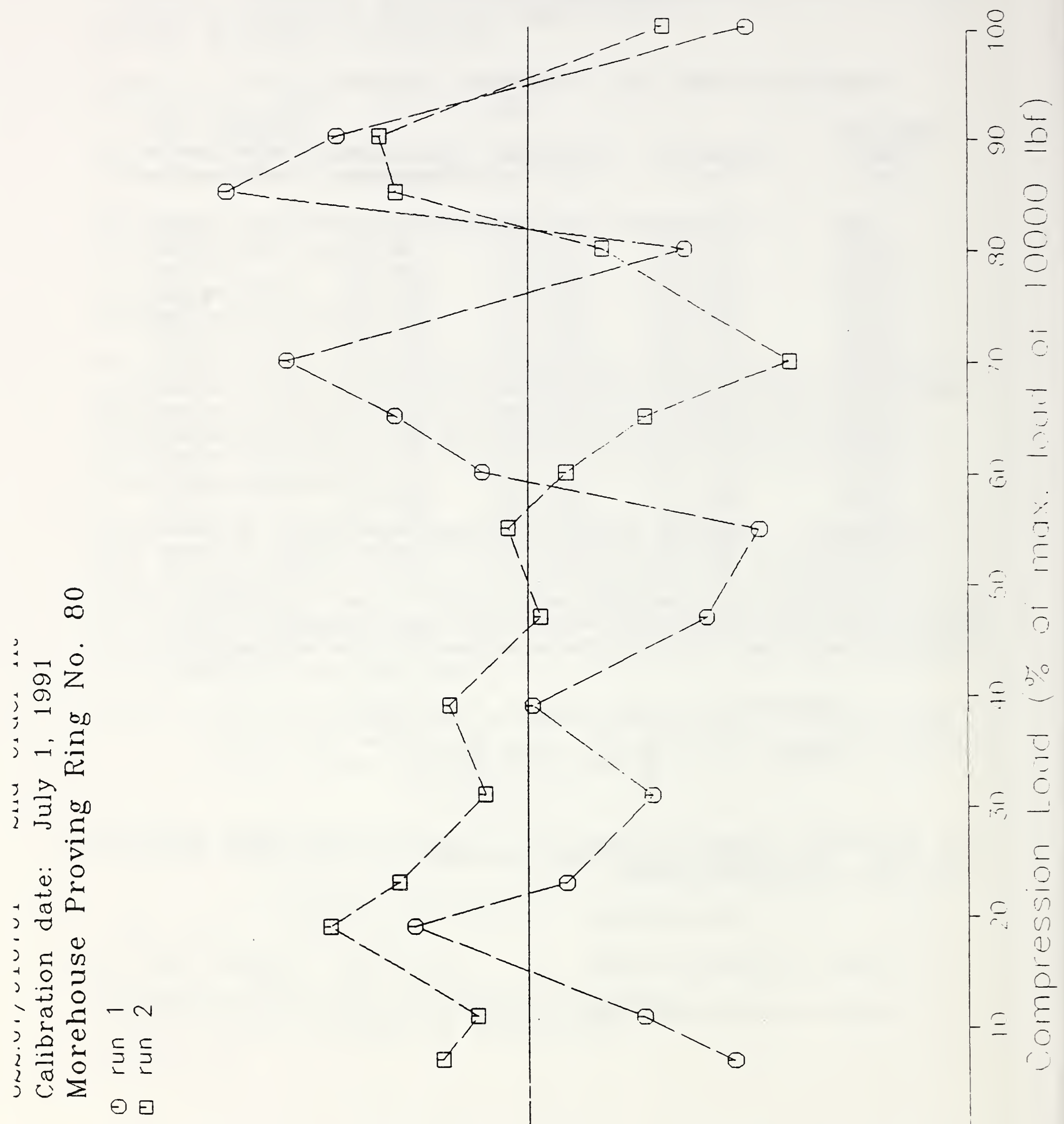

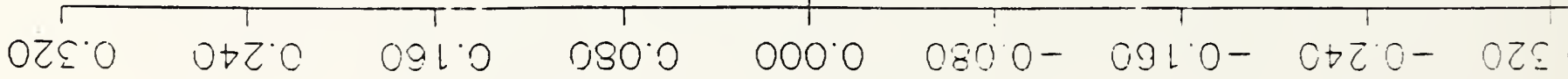

1- ol: (zndzno xoul to \%) uo!zonar 
$822.07 / 910701$

Calibration Date: July 1, 1991

Morehouse Proving Ring No. 80

Capacity 10000 lbf Compression

\section{Compression Run Deviations}

\section{Applied Load (Ibf)}

700
1100
1900
2300
3100
3900
4700
5500
6000
6500
7000
8000
8500
9000
10000

Deviation Run 2

0.05

0.03

0.12

0.08

0.03

0.05

$-0.01$

0.01

$-0.02$

$-0.07$

$-0.16$

$-0.04$

0.08

0.09

$-0.08$
Predicted

Response

56.70

89.12

154.13

186.72

252.07

317.65

383.46

449.49

490.87

532.35

573.91

657.29

699.12

741.04

825.13 
Appendix B

Micrometer Head Calibration 
U. S. DEPARTMENT OF COMMERCE

National Institute of Standards and Technology

Gaithersburg, Maryland 20899

REPORT OF TEST No. 731/G46306-91

For: Boeckeler Instruments Micrometer

NBS Number 179139

Submitted by: $\quad$ T. Robert Shives

NIST Division 855

The micrometer submitted was tested against a high accuracy coordinate measuring machine. The results of the calibration are given in the table below.

$\begin{array}{lll}\begin{array}{l}\text { Nominal } \\ \text { (inch) }\end{array} & \begin{array}{l}\text { Actual } \\ \text { (inch) }\end{array} & \begin{array}{l}\text { Correction } \\ \text { (inch) }\end{array} \\ 0.00000 & 0.00000 & 0.00000 \\ 0.10200 & 0.10201 & 0.00001 \\ 0.20400 & 0.20401 & 0.00001 \\ 0.30600 & 0.30600 & 0.00000 \\ 0.40800 & 0.40799 & -0.00001 \\ 0.51000 & 0.50999 & -0.00001 \\ 0.61200 & 0.61199 & -0.00001 \\ 0.71400 & 0.71399 & -0.00001 \\ 0.81600 & 0.81598 & -0.00002 \\ 0.91800 & 0.91798 & -0.00002 \\ 1.0000 & 0.99998 & -0.00002\end{array}$

The test data was corrected to standard conditions ( $20^{\circ} \mathrm{C}$ ) using a thermal expansion coefficient of $11.5 \times 10^{-6} /{ }^{\circ} \mathrm{C}$. The uncertainty estimated from the repeatability of the data and the accuracy of the machine is 0.00002 in.

Measurements were made by

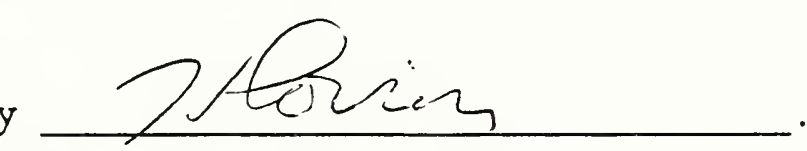

For the Director,

National Institute for Standards and Technology

Order No. $855-4644$

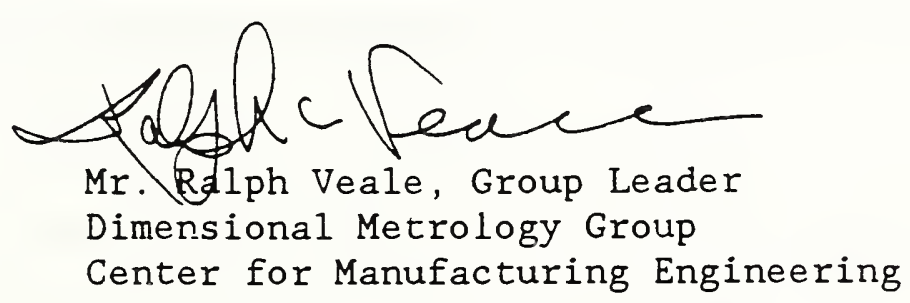

Group Control M3882

Date: August 6, 1991 



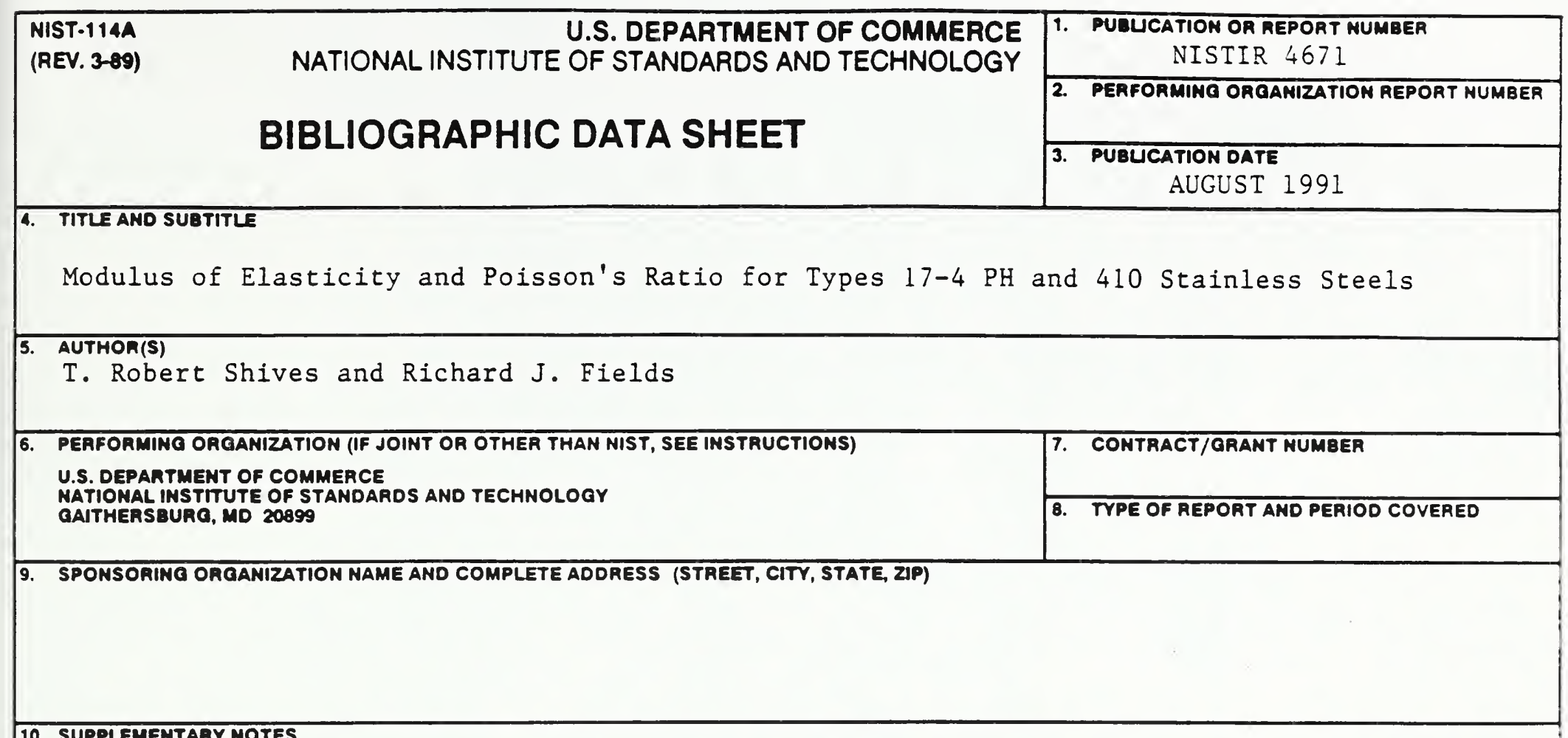

10. SUPPLEMENTARY NOTES

DOCUMENT DESCRIBES A COMPUTER PROGRAM; SF-185, FIPS SOFTWARE SUMMARY, IS ATTACHED.

19. ABSTRACT (A 200-WORD OR LESS FACTUAL SUMMARY OF MOST SIONIFICANT INFORMATIOH. IF DOCUMENT IMCLUDES A SIONIFICANT BIBUOQRAPHY OA UTERATURE SURVEY, MENTION IT HERE.)

Values of the modulus of elasticity and Poisson's ratio in compression were determined for three samples of type 17-4 PH stainless steel and for one sample of type 410 stainless steel. The three samples of the 17-4 PH were from different locations of one bar of material. The results obtained agree well with values reported in the literature.

12. KEY WORDS (6 TO 12 ENTAIES; ALPHABETICAL ORDEA; CAPITALZE ONLY PROPEA MAMES; AND SEPARATE KEY WORDS BY SEMICOLONS)

17-4 PH stainless steel; 410 stainless steel; compression testing; modulus of elasticity; Poisson's; stainless steel Fon OfFICIAL Distribution. DO NOT RELEASE TO NATIONAL TECHNICAL INFORMATION SERVCE (NTIS). ORDER FROM SUPERINTENDENT OF DOCUMENTS, U.S. OOVERMMENT PAINTINO OFFICE, WASHINGTON, DC 20402.

ORDER FROM MATIONAL TECHMICAL INFORMATION SERVCE (NTIS), SPRIMGFIELD, VA 22161. 



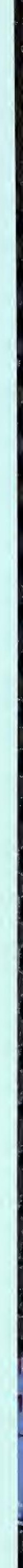


